Validity and worth in the science curriculum: learning school science outside the laboratory

\author{
Martin Braund, \\ Department of Educational Studies, \\ University of York, Heslington, York YO10 5DD, UK \\ e-mail: mb40@york.ac.uk
}

and

Michael Reiss,

Institute of Education, University of London,

20 Bedford Way, London WC1H OAL, UK

e-mail:․r.reiss@ioe.ac.uk 


\title{
Validity and worth in the science curriculum: learning school science outside the laboratory
}

\begin{abstract}
It is widely acknowledged that there are problems with school science in many developed countries of the world. Such problems manifest themselves in a progressive decline in pupil enthusiasm for school science across the secondary age range and the fact that fewer students are choosing to study the physical sciences at higher levels and as careers. Responses to these developments have included proposals to reform the curriculum, pedagogy and the nature of pupil discussion in science lessons. We support such changes but argue from a consideration of the aims of science education that secondary school science is too rooted in the science laboratory; substantially greater use needs to be made of out-of-school sites for the teaching of science. Such usage should result in a school science education that is more valid and more motivating and is better at fulfilling defensible aims of school science education. Our contention is that laboratory-based school science teaching needs to be complemented by out-of-school science learning that draws on the actual world (e.g. through fieldtrips), the presented world (e.g. in science centres, botanic gardens, zoos and science museums) and the virtual worlds that are increasingly available through information and communications technologies (ICT).
\end{abstract}

Keywords: out-of-school science; authenticity; museums; fieldtrips; curriculum aims 
We wish to locate our arguments about the contribution of out-of-school sites for science education within the growing literature on the aims of school science (Reiss, in press). It is our contention that meeting these aims argues strongly for the role both of the science laboratory and of out-of-school sites. Given the current emphasis on laboratories for school science, this requires a shift towards extra-laboratory settings. We will argue that these settings can be conceptualised as occurring in the actual world (accessed through such things as fieldtrips), the presented world (accessed through science centres, botanic gardens, zoos, science museums, etc.) and the virtual worlds that are increasingly available through information and communications technologies (ICT).

\section{The aims of school science education}

\section{Supply of future scientists}

A frequent aim of many science courses has been for them to provide a preparatory education for the small proportion of individuals who will become future scientists (in the commonly understood sense as employed professionals). This aim has been widely and in our view validly critiqued on democratic grounds (e.g. Millar and Osborne, 1998). Essentially, what of the great majority of school students who will not become such scientists?

Nevertheless there may be a danger that attempts to craft new science courses so as to make them more relevant to all pupils will result in some of those who would previously have gone on to studying science not doing so. It is possible that precisely those features that make certain science courses unpopular to the majority of students (impersonality, objectivity, the absence of value judgements) may make them attractive to those with a particular bent for mainstream professional science (Reiss, 2005).

In actuality, pressures from universities and other sources such as industry (cf. Hart, 1998) mean that it is extremely unlikely that school science courses will no longer serve to prepare students for a future as scientists and science technicians. It is more likely 
that we will see some sort of diversification within school science courses though this, of course, runs the risk that certain groups of students (characterised by sex, socioeconomic status, ethnicity or whatever) will be more likely to opt for what are seen or become seen by some as lower status routes.

\section{Scientific literacy}

Although there has been considerable debate as to the meaning of the term 'scientific literacy' (e.g. Miller, 1983; Hand et al., 2003), sufficient agreement about the term exists for it to be used profitably. Generally, scientific literacy is seen as a vehicle to help tomorrow's adults to understand scientific issues (Gräber and Bolte, 1997). The basic notion is that science education should aim to enhance understanding of key ideas about the nature and practice of science as well as some of the central conclusions reached by science.

Perhaps to be included within this category is the argument that to be an educated person in the $21^{\text {st }}$ Century is to understand something of science (e.g. Shamos, 1995). This is the 'science as culture' argument; that science is as worth studying in itself, as are, for example, literature and the arts.

\section{Individual benefit}

Many science courses hope that as a result of what is learnt pupils both now and in the future, as adults, will be able to benefit from it. At its most straightforward this might be by entering paid employment that draws on what they have learnt in science. Although, as noted above, most students do not enter such careers they too may still benefit individually from their school science. For example, in most science courses, in countries round the world, it has long been accepted that one of the justifications for the inclusion of certain topics is that knowledge and understanding of them can promote human health. Such topics may include learning about infectious diseases, diet, reproduction and contraception and the abuse of drugs (including smoking and alcohol). 
Another aspiration of school science is that it equips the school leaver with a functional science to operate or understand technology, e.g. the ability to wire a plug, an understanding of how a computer, "phone or the domestic electricity system works and so on. These aspirations have been challenged on the grounds that such functionality is rarely useful. In a review of the knowledge actually used by members of the public (i.e. non-scientists) to function effectively in particular settings, Ryder (2001) concluded that the amount of formal scientific knowledge needed was quite limited. Constructing a science curriculum on the basis of what science members of the public might need is likely to result in less emphasis being paid to content knowledge and more to ways of accessing and evaluating scientific knowledge than is typically provided by school science courses.

\section{Democracy}

Longbottom and Butler have put forward the argument that "the primary justification for teaching science to all children is that it should make a significant contribution to the advancement of a more truly democratic society" (Longbottom and Butler, 1999: 474). They go on to argue that, in a way reminiscent of inquiry-based science, "children should adopt many of the critical and creative attributes of scientists (giving students the skills to collect, seek and evaluate evidence and to take part in reasoned debate)" (p. 487).

The argument that school science education should promote democracy is related to the argument that it should be for citizenship (Jenkins, 1999; Thomas, 2000; Kolsto, 2001) though it could be argued that this is a reductionist and partial view of what is involved in being a citizen. A strong version of this argument entails using knowledge about what a democracy is and how it functions to bring about change. This version is closely allied to claims that the aim of school science education should be to effect social justice or socio-political action. 
Recent years have seen a growth in the idea that school science education should serve to achieve social justice, including, for example, a more equitable distribution of resources. For example, Calabrese Barton, who has worked with homeless children in the USA to develop a science curriculum and practice that is more appropriate for them and strives for greater social justice, has shown that active participation in science lessons, and 'real' learning about science, take place when children believe that their work can bring about improvements for themselves, their friends and their families (Calabrese Barton, 1998, 2001).

Akin to science education for social justice is the notion of science education for sociopolitical action as described by Roth and a number of his collaborators (Roth and Désautels, 2002). Lee and Roth (2002) provide a case study of a community-based activist project, the Henderson Creek Watershed Restoration Project. The goal of the project being to protect and enhance the Henderson Creek stream system by providing enough water for both the ecological and the human needs of the watershed.

\section{Criticality}

Many in education are in favour of critical thinking where 'critical' is taken to mean rigorous, analytical, logical, open-minded and penetrating, and thinking has elements of reflective scepticism. Oulton et al. (2004) argue that science education needs both teachers and learners to reflect "critically on their own stance and recognize the need to avoid the prejudice that comes from a lack of critical reflection" (Oulton et al., 2004: 420). They go on to criticise the notion that teachers should maintain neutrality in the teaching of controversial issues arguing that better science education will result when we have pedagogical approaches that "motivate teachers, as much as possible, to share their views with pupils and make explicit the way in which they arrive at their own stance on an issue" (p. 420). 
The thrust of Oulton et al. (2004) takes us beyond straightforward critical thinking in the direction of criticality. Criticality goes beyond critical thinking to use the results of such thinking to achieve social change. Hildebrand (2001) has argued in favour of what she terms 'critical activism' in science education. She urges that there should be both participation in science (doing science) and participation in debates about science (challenging science).

\section{Attitudes to school science and the potential of out-of-school learning}

In many developed countries of the world, science education is seen to be in severe difficulties. Pupils' attitudes to school science decline progressively across the age range of secondary schooling and declining numbers of students are choosing to study science (particularly the physical sciences) at higher levels and as a career (Goodrum et al., 2001; Osborne and Collins, 2001; Haste, 2004; Sjøberg et al., 2004). For some time science educators in many countries have expressed concerns that current provision in schools (especially at age 14-16 years) is all too often boring, irrelevant and outdated; designed mainly to educate a minority of future scientists, rather than equipping the majority with the scientific understanding, reasoning and literacy they require to engage as citizens in the $21^{\text {st }}$ Century (Sjøberg, 1997; Millar and Osborne, 1998; Goodrum et al., 2001).

In contrast to this, the science and the ways in which it is communicated, in places outside schools (science museums, hands-on centres, zoos, botanical gardens, etc.) is seen as exciting, challenging and uplifting (Braund and Reiss, in press). In these places new technologies and advances in our understanding of learning in informal settings have been put to good use (Popli, 1999; Godin and Gingras, 2000). In the UK, educational provision in the informal sector has been stimulated by government policy shifts and by large-scale investments (Anderson, 1997). In pupils' homes, the growth in use of multi-channel television and the internet increasingly provide sources of highquality and attractively packaged information about science and issues of relevance to young people. A recent survey in the UK showed that time spent using computers in the home (excluding gaming) now greatly exceeds that spent at school (DfES, 2002). 
Newspapers and magazines offer additional rich sources of science and debates about recent, relevant and often controversial issues (Jarman and McClune, 2004).

The educational experience of science for learners at home and in the informal sector can therefore be in stark contrast to what is on offer in schools. A conundrum for science educators is that pupils of school age are being turned off science in their schools yet the same pupils may be entertained and engaged by science outside them. Furthermore, the above discussion of the aims of school science illustrates the extent to which these aims do not require all of school science to be spent in laboratories; indeed, the reverse. To satisfy aims such as science for socio-political action would mean that school science education cannot be confined to the laboratory.

Pupils of school age spend about two-thirds of their waking lives outside formal schooling yet educators tend to ignore, or at least play down, the crucial influences that experiences outside school have on pupils' knowledge and understandings, and on their beliefs, attitudes and motivation to learn. The value that pupils themselves place on these experiences, over some of those provided by schools, in helping them learn science was revealed in a survey of pupils' views about learning science carried out recently in the UK. Out of eleven alternative strategies for learning science, 'going on a science trip or excursion', was rated the most enjoyable way of learning and the fifth most useful and effective (Cerini et al., 2003).

In recent years there has been a huge investment to provide opportunities to communicate science in museums, science centres, botanic gardens, zoos, field centres and at industrial and commercial sites. In the UK this development was accelerated by grants totalling over $£ 1$ billion awarded by the Millennium Commission so that by 2004 it was estimated that every major centre of population in the UK was now served by at least one such provider (Ecsite-uk, 2005).

Here we wish to explore the contribution that out-of-school contexts can make to pupils' learning in science. Our view is that these contexts should be seen as complementary to formal schooling rather than as in competition with it. We argue that 
school science is currently modelled on an outdated and restricted representation of science, so that virtually all school science teaching is undertaken (or strives to be undertaken) in laboratories, and that drawing on the wider community of science and ways in which science is undertaken and from the range of contexts in which it is communicated outside schools will result in a more authentic science curriculum. Additionally this representation is closer to contemporary science and thereby a more valid model of the real world of science. In this we do not seek to downgrade the role of the laboratory in school science. Indeed many activities such as investigations of chemical reactions, observations using microscopes, procedures in microbiology, explorations of electrical circuits and so on, by their very nature, will always be taught there.

The notion of authenticity in the context of science education has been raised by a number of authors (Roth, 1997; Hodson, 1998; Woolnough 1998; Bencze and Hodson, 1999). Bencze and Hodson (1999) warn that authenticity is an elusive and problematic notion with diverse meanings and implications for curricula. There seems, though, to be some consensus that authentic school science should provide experiences that are more in line with the sorts of activities that scientists and technologists do in the real world of science and that such experiences should include student-directed tasks and more openended enquiries. In other words, authenticity applies both with regard to the subject matter of science as practised out of school ('experiences that are more in line with the sorts of activities that scientists and technologists do in the real world of science') and with regard to school students themselves ('such experiences should include studentdirected tasks and more open-ended enquiries').

\section{The contribution of out-of-school contexts to learning science}

In this section we present what we believe are key contributions that out-of-school contexts can make to the learning of science for school-aged pupils. Learning can be initiated by the home or by the school and we believe that both are important. For example, a school visit to a museum, an industrial site, planetarium or zoo might be planned and led by the teacher as part of the science curriculum or as an extra-curricular 
activity. Home-initiated learning might be home-situated, such as using the internet, watching TV or reading printed media, or it can take place out-of-home in the case of such things as bird-watching, walking, playing sport or visiting museums. Here we largely focus on what schools can do to promote learning but one of the challenges for schools is to do their utmost to ensure that what they provide by way of learning experiences in science, inside and outside the laboratory, usefully takes place alongside what their pupils are learning about science independent of school activities.

Five ways in which out-of-classroom contexts can add to and improve the learning of science are described:

i) Improved development and integration of concepts.

ii) Extended and authentic practical work.

iii) Access to rare material and to 'big' science.

iv) Attitudes to school science: stimulating further learning.

v) Social outcomes: collaborative work and responsibility for learning.

Improved development and integration of concepts

One of the first things teachers often want to know if thinking of investing time, effort and finance in out-of-school learning is 'What is the pay-off in terms of my pupils' knowledge and understanding of science?'. To a certain extent we think this may be a case of asking the wrong question and we return to this point later. Nevertheless, it is a reasonable and natural thing to ask and although the research evidence of learning gains for pupils from out-of-school science learning is still rather scant, there are notable exceptions. For example, Dierking and Falk (1994) and Falk and Dierking (2000) review studies that have detected improved understanding of such classic school science concepts as force and motion following museum visits; the influence of home-initiated activities in the environment (such as bird-watching and wildlife walks with parents) has been found to have an impact on pupils' performance on animal classification tasks (Braund, 1991); visits to industrial sites have been found to improve pupils' (and 
teachers') knowledge of industrial processes and this learning is long-term (Parvin and Stephenson, 2004).

\section{Extended and authentic practical work}

By extended practical work we mean the opportunity to engage in activity that would not be possible in the normal school laboratory either because of safety considerations or because of the new opportunities afforded by working in outside spaces. These include, for example: launching rockets, ecological surveys, observation of the night sky, large scale experiments of combustion and so on. Practical science in out-of-school contexts is more 'authentic' than much of what goes on in school laboratories when it helps demonstrate or replicates the sort of work that scientists frequently undertake in modern science or if it is perceived as having relevance to solving real-life problems. For some authors, reflecting on authentic school science (see for example, Woolnough, 1998), fieldwork provides the ideal example of authentic practical work, mainly because it provides an opportunity to challenge the myths propagated about practical science in a school laboratory (Hodson, 1998).

It is important to emphasise, however, that out-of-school learning should not be equated only with ecology. There are many examples from other areas of science that provide good examples of more authentic practical experiences than often occurs in school. For example, pupils have been found to value practical work where it is seen in a different context to that in school, e.g. in the case of visits to industrial or commercial premises (Parvin and Stephenson, 2004). Theme parks are popular with pupils and offer the chance to engage with advanced physics (e.g. studies of acceleration and pendula) applied in a leisure environment (Swinbank and Lunn, 2004). Additionally, children's museums provide first-hand experiences with authentic objects and are popular with younger learners (Moussouri, 1997). Indeed, museums for visitors of all ages are increasingly providing experiences that actively engage visitors (Black, 2005). 
A traditional role of places such as museums, botanic gardens and zoos is to act as a repository of typical or rare (even unique) specimens and artefacts forming a reference point for the accumulation and enhancement of scientific knowledge. Collections provide opportunities for pupils to see and sometimes handle specimens and artefacts, raise questions about their origins and significance and place them within histories illustrating the development of technologies and scientific thought. In this way artefacts and collections and the stories associated with them help teach about the ways in which scientific and technological knowledge has been generated and the social enterprise in which those who engaged in this work operated.

By 'big science' we mean the sort of science that requires large or sophisticated equipment (e.g. radio telescopes, particle accelerators, electron microscopes, large-scale DNA sequencing equipment) and often collaboration on an international scale (Swinbank and Lunn, 2004). People can find 'big' science inspirational and controversial. On the one hand, there is the excitement of research into big questions such as 'What are we made of?' and 'What will be the ultimate fate of the universe?'. On the other hand, there are questions about whether the financial costs of the enterprise can be justified. A visit to a research telescope, space centre or genome campus is an excellent way to give pupils an appreciation of 'big' science.

Artefacts, collections and the histories that surround them as well as examples of big science have much to offer in terms of helping students appreciate the nature of science and the scientific enterprise, an area that few pupils of school age seem to be aware of (Driver et al., 1996).

Attitudes to school science: stimulating further learning

Given the typical decline, discussed above, in pupil interest in school science as pupils progress through secondary school, a fundamental issue is the way in which out-ofclassroom contexts can provide new connections with science and stimulate people to 
think more deeply about science and its relationships with society. In a review of research in science centres, Rennie and McClafferty (1996) advised re-focussing concerns about outcomes of learning in these more informal settings away from the understandable concerns of most teachers to see cognitive gains in their pupils towards a deeper relationship with learning:

The key question is not: do people learn science from a visit to a science centre? But, do science centres help people to develop a more positive relationship with science?

(Rennie and McClafferty, 1996: 83)

We see this as crucial in pointing out the level of peoples' future engagement with science and therefore in helping raise levels of scientific literacy. If the pay-off from out-of-school learning of science that is integrated within a more authentic science curriculum is more engaged and positively oriented science students then school learning must surely benefit.

Social outcomes: collaborative work and responsibility for learning

Schools are places where learning is structured into topics, dictated by the requirements of examinations and confined by timetables. In out-of-school contexts (e.g. a field trip) new opportunities arise where activity, although of course subject to new constraints, is less constrained by school bells and lesson times. Work can be more extensive and thorough and provides more autonomy for learners. There are opportunities for pupils to take responsibility for themselves and others, by working in teams and for active consideration of the environment (Amos and Reiss, in press). For pupils, the benefits that accrue from collaborative work and socialisation are particularly strong when a residential experience is included (Bebbington, 2004). We shall now go on to argue that a wider conceptualisation of the locations within which worthwhile school science can take place (i.e. including out-of-school contexts) to a certain extent parallels developments in conceptualisations about the workings of science itself. 


\section{A model for more authentic school science}

In a book that brought together much of his life's work, John Ziman (2000) characterised the view that science has an all-conquering intellectual method as 'the Legend'. As he put it:

The moral basis for the defence of science must be a clear understanding of its nature and of its powers. One might have thought that this understanding was already widely shared, especially among working scientists.

Unfortunately, this is not the case. Most people who have thought about this at all are aware that the notion of an all-conquering intellectual method is just a legend. This legend has been shot full of holes, but they do not know how it can be repaired or replaced. They are full of doubts about past certainties, but full of uncertainties about what they ought now to believe.

(Ziman, 2000: 2)

Ziman went on to argue that there are, nowadays, new modes of knowledge production in science. He talks about the heyday of science between, say, 1850 and 1950, whereas today we live in an era of 'post-academic science' characterised by a great emphasis on work that is transdisciplinary, collective, more utilitarian, more political, industrialised and more bureaucratic. For the purposes of this paper, we wish to emphasise in particular the way in which contemporary science draws on a wide range of inputs, experiences and technologies in a variety of places. Of course, laboratories are important as we stated earlier but for almost every scientific phenomenon, the laboratory is not the site but only one site of knowledge production. Once again we emphasise our intention is not to denigrate or get rid of school laboratories; rather it is to see them as just one locus within which school scientific learning takes place.

We would like to suggest a model for more authentic school science that draws on the following premises:

1. There is a correspondence between how science has changed over the past 150 years and how school science needs to change. 
2. An emphasis is increasingly seen in school science courses away from 'transmission learning' aimed at individuals towards 'constructivist learning' requiring more engaging pedagogic strategies, e.g. through group discussions.

3. School science needs to draws on more sites of valid data gathering and knowledge production (Braund and Reiss, in press).

\section{Practicalities and potentialities}

We acknowledge that the science classroom, the laboratory, has a special place for the great majority of secondary science teachers. We can see two principal reasons for this:

1. The laboratory has been seen to characterise science and as the place where scientific knowledge and understanding are shaped. Laboratory-produced knowledge is then seen as having higher worth than that produced in other settings.

2. While there is some variation among science teachers - so that, for example, a science teacher with a specialism in ecology may feel most at home on a biology field trip - most science teachers were reared within a model in which the well stocked laboratory played a key, possibly the central role. Teaching within a laboratory then becomes a part of teachers' professional identity (reinforced, we suspect, by such markers as lab coats and certain items of apparatus/furniture, such as fume cupboards - even when rarely used). In a number of well resourced countries secondary science teachers enjoy certain 'perks' as a result of their laboratories: they have laboratory technicians to assist them; they have a 'prep' room which may double-up as a place for relaxation or a cup of coffee; science laboratories are less likely than 'normal' classrooms to be commandeered for other activities because they are relatively inflexible and, perhaps, somewhat alienating to non-science teachers.

As a consequence of these perceived traditional benefits there can be resistance to relying less on the laboratory for learning in school science. Such practical difficulties as the trouble and cost of arranging visits to out-of-school sites are additional factors 
that might constrain science teachers to the laboratory. These difficulties include concerns about increasingly litigious parents, should something go wrong. Schools have to think carefully about the choice of sites and, as one of the referees of this paper pointed out, whether or not there are certain 'no go' areas, “e.g. a drug rehabilitation unit to consider the effects of recreational drugs, a cathedral to discuss evolution/intelligent design, an HIV/AIDS clinic to discuss sex education and safe sex, a laboratory that uses animals in experiments to discuss vivisection". We address some of these issues and concerns in more detail elsewhere (Reiss and Braund, 2004). Here it suffices to say that issues about the suitability of out-of-school sites are not fundamentally different from issues about the suitability of school visitors, textbooks and other conventional school teaching materials for the treatment of such controversial yet relevant issues requiring pupils to engage in thinking about science within moral and ethical frameworks.

To illustrate how out-of-school learning goes beyond what is possible in the school laboratory in providing for a more authentic learning of science, we close with three examples; the potential of ICT at home, the potential of botanic gardens and the potential of chemistry trails. We have deliberately chosen three somewhat conservative examples. Attracted as we are to the possibility that out-of-school learning can help to transform science education, there is much to be said for starting with the familiar. Such an approach is likely to be adopted by more teachers than a more radical programme.

That ICT can assist in the learning of science is hardly a novel idea. However, Wellington and Britto (2004) look in particular at the implications of ICT use at home for science teachers in school. One point they make is particularly apposite to the notion of authentic science, and that is the control that home use of ICT gives to the learner. Such control can be threatening to teachers since there is a tension between conceptions of classroom learning and out-of-school learning with ICT. If though, such threats can be overcome, learning science through ICT can complement learning through laboratory practice. One point we would stress is that ICT can play a significant role in all three types of out-of-school learning we have discussed. For example, dataloggers have long been used on fieldtrips (the actual world) to provide information about environmental conditions and, more recently, wireless, mobile technologies are being 
developed to extend learning possibilities in the field (e.g. the Ambient Wood project see Price and Rogers (in press). Museums (the presented world) are increasingly using ICT in interactive exhibits while the use of ICT for the virtual world is obvious and expanding greatly; for just one example, see the Gary Skinner's Virtual Rocky Shore Tour on the British Ecological Society's website: www.britishecologicalsociety.org/education2/index.php?cat=17 $>$ Education and Careers > Students Age 16+ > Habitats > Virtual Rocky Shore Tours).

Botanic gardens are perhaps less well known than science museums, science centres and zoos as sites of science learning yet they have a long history in education and great potential in developing scientific, including environmental, literacy (Johnson, 2004). However, it is not a straightforward matter to maximise the educational benefits of a visit to a botanic garden (or any other 'placed' location for out-of-school science education):

Obstacles to an effective teaching and learning situation stem firstly from the cognitive frameworks that the children bring with them. In the classroom they develop a routine for lessons, some of which are derived from formalised teaching strategies. If the themes, sequences, interpretative materials or narratives used in the garden are outside these compartmentalised frameworks, children may not recognise the visit as a lesson. They might also disregard what they come to understand during the experience because it is their own construction of knowledge.

(Johnson, 2004: 79)

This can be read as a form of learned helplessness. It illustrates the need, if schools have built up effective barriers to knowledge (with valued knowledge being in laboratories or school libraries and perhaps dissociated from 'fun' activities, such as a day out) to enable such barriers to be deconstructed. With their wealth of overseas plants, visits to botanic gardens can be used as a springboard for teaching about global socio-scientific issues such as conservation, sustainability, climate change, food production and inequalities. Pupils could grow food themselves (e.g. by reclaiming disused allotments), develop electronic links with overseas schools and so on. 
The chemistry laboratory is perhaps seen by secondary pupils as being definitive of school secondary science. Indeed, it has been argued that:

To most students and their teachers, chemistry is something which happens in test tubes in laboratories or in tangled masses of pipes in factories. They need to be shown that chemistry is not something remote but that it is going on all around us, all the time.

(Borrows, 2004: 151)

Of course, there are aspects of chemistry that can best be taught in the laboratory. But chemistry trails are a way of connecting school chemistry to the real world. In the mantra of many students: it can make chemistry 'relevant'. Chemistry trails are not difficult to create and Borrows (2004 and references therein) provides many suggestions; for example, they can be used to study such topics in applied chemistry as building materials and air pollution. They can thus help teachers extend traditional school chemistry into earth sciences and physical geography. In addition, pupils can create their own trails too.

\section{Conclusions}

Attempts to deal with the perceived problems of declining pupil attitudes to school science and the low take up of science in the post-compulsory phase have looked at such issues as the curriculum, pedagogy, pupil practical work and pupil discussion (Millar and Osborne, 1998; Woolnough, 1998; Mortimer and Scott, 2003) and proposed changes. We support such developments. Our purpose in this paper is to argue that the site of learning needs re-examination too. Our contention is that school science is generally too restrictive: for all the undoubted value of and continued need for school laboratories, they constrain the activities that take place and fail to meet a number of the current aims of school science education. As a representation of contemporary science, the mainly in-laboratory school model falls short. In the real world of science, laboratory time is expensive and costs must be justified. Scientists today are as likely to 
spend time reading, working on computer models and simulations, in meetings and conferences, doing field tests as they are in the laboratory.

Furthermore, modern science is highly collaborative and multidisciplinary as the following example seen at a recent international science fair on new biotechnologies shows. Having collected a number of shells from fieldwork, a zoologist marked up specimens with a felt pen and observed the particularly absorbent properties of lobster and crab shells. The zoologist talked with a microbiologist who offered to study their structure; a molecular chemist extracted absorbent compounds from the shells before involving a chemical engineer in providing the product as small pellets. Process engineers finished the development providing a method to use the pelleted shell product to filter polluted water. This is just a single illustration but it shows the way in which the current reliance on a mainly in-laboratory environment and solitary working methods of school science leads to an attenuated presentation of science - one that is less authentic as well as less motivating.

Out-of-school science activities can occur in a number of forms. Fieldtrips - whether residential ones (e.g. for ecology) or short ones (e.g. chemistry trails) - allow pupils to engage with science in what can be termed the actual world. Outings to museums, botanic gardens, zoos and science centres allow pupils to engage with science in what can be termed the presented world (cf. Macdonald, 1998). Richer use of ICT allows pupils to engage with science in virtual worlds. Of course, the 'actual' world encountered on fieldtrips is itself a 'presented' world and the 'virtual' worlds of ICT have their actual components too (for example, when on-line video cameras are used to monitor the behaviour of animals - the number of these now available for science education is huge).

Museums and other informal sites of learning have had to work hard to attract visitors precisely because attendance at them is not compulsory. In almost all countries school science has both the advantages and disadvantages of being a compulsory subject and one that is greatly valued by those who control the curriculum, albeit not always valued by those who sit in the resulting lessons. What is clear is that in an increasing number of countries the quality of presentations of science in the media (including TV) mean that 
the days are long gone when pupils of secondary age would be impressed by a demonstration of a collapsing can when attached to a vacuum pump, the growth of copper sulphate crystals or the meanderings of desiccated woodlice or dazzled maggots (Braund and Reiss, in press).

What we need is a great deal more thought about the potential for learning science outside the classroom (Falk, 2001; Braund and Reiss, 2004). If we can get it right, there is every chance that the school laboratory and teacher-enabled discussions among pupils in science classes can complement and extend out-of-school learning. If we get it wrong, not only may we continue to lose many of our best students from science but the very worth of school science may increasingly be questioned by those in power who sanction the use of large amounts of money on school science laboratories, technicians and teachers.

\section{References}

Amos, R. and Reiss, M. (in press) What contribution can residential field courses make to the education of 11-14 year-olds?, School Science Review.

Anderson, D. (1997) A common wealth: museums and learning in the United Kingdom (London, Department of National Heritage).

Bebbington, A. (2004) Learning at residential field centres, in: M. Braund and M. J. Reiss (Eds) Learning science outside the classroom (London, RoutledgeFalmer), 55-73.

Bencze, L. and Hodson, D. (1999) Changing practice by changing practice: toward more authentic science and science curriculum development, Journal of Research in Science Teaching, 36, 521-539.

Black, G. (2005) The engaging museum: developing museums for visitor involvement (London, RoutledgeFalmer).

Borrows, P. (2004) Chemistry trails, in: M. Braund and M. J. Reiss (Eds) Learning science outside the classroom (London, RoutledgeFalmer), 151-68.

Braund, M. (1991) Children's ideas in classifying animals, Journal of Biological Education, 25, 103-10.

Braund, M. and Reiss, M. J. (Eds) (2004) Learning science outside the classroom 
(London, RoutledgeFalmer).

Braund, M. and Reiss, M. J. (in press) Towards a more authentic science curriculum: the contribution of out-of-school learning, International Journal of Science Education.

Calabrese Barton, A. (1998) Teaching science with homeless children: pedagogy, representation, and identity, Journal of Research in Science Teaching, 35, 379-94.

Calabrese Barton, A. (2001) Science education in urban settings: seeking new ways of praxis through critical ethnography, Journal of Research in Science Teaching, 38, 899-917.

Cerini, B., Murray, I. and Reiss, M. J. (2003) Student review of the science curriculum: major findings (London, Planet Science).

DfES (Department for Education and Skills) (2002) Impact2: final report (London, Department for Education and Skills/British Educational and Technology Agency).

Dierking, L. D. and Falk, J. H. (1994) Family behaviour in informal science settings: a review of research, Science Education, 78, 57-72.

Driver, R., Leach, J., Millar, R. and Scott, P. (1996) Young people's images of science (Buckingham, Open University Press).

Ecsite-uk (2005) www.ecsite-uk.net (accessed 18 March 2006).

Falk, J. H. (Ed.) (2001) Free-choice science education: how we learn science outside of school (New York, Teachers College Press).

Falk, J. H. and Dierking L. D. (2000) Learning from museums (Walnut Creek USA, AltaMira Press).

Godin, B. and Gingras, Y. (2000) What is scientific and technological culture and how is it measured? A multidimensional model, Public Understanding of Science, 9, 43-58.

Goodrum, D., Hackling, M. and Rennie, L. (2001) The status and quality of teaching and learning of science in Australian schools (Canberra, Commonwealth Department of Education, Training and Youth Affairs).

Gräber, W. and Bolte, C. (Eds) (1997) Scientific literacy: an international symposium IPN 154 (Kiel, Institut für die Pädagogik der Naturwissenschaften an der Universitatät Kiel). 
Hand, B. M., Alvermann, D. E., Gee, J., Guzzetti, B. J., Norris, S. P., Phillips, L. M., Prain, V. and Yore, L. D. (2003) Message from the "Island Group": what is literacy in science literacy?, Journal of Research in Science Teaching, 40, 607-15.

Hart, C. (1998) Addressing participation and the quality of learning through curriculum change: some lessons from the experience of VCE Physics, Australian Educational Researcher, 25(2), 19-37.

Haste, H. (2004) Science in my future: a study of values and beliefs in relation to science and technology amongst 11-21 year olds (London, Nestle Social Research Programme).

Hildebrand, G. M. (2001) Con/testing learning models, Conference paper presented at the Annual Meeting of the National Association for Research in Science Teaching, St Louis, 25-28 March.

Hodson, D. (1998) Is this really what scientists do? Seeking a more authentic science in and beyond the school laboratory, in: J. Wellington (Ed.) Practical work in school science. Which way now? (London: Routledge), 93-108.

Jarman, R. and McClune, B. (2004) Learning with newspapers, in: M. Braund and M. J. Reiss (Eds) Learning science outside the classroom (London, RoutledgeFalmer), 185-205.

Jenkins, E. W. (1999) School science, citizenship and the public understanding of science, International Journal of Science Education, 21, 703-10.

Johnson, S. (2004) Learning science in a botanic garden, in: M. Braund and M. J. Reiss (Eds) Learning science outside the classroom (London, RoutledgeFalmer), 75-93.

Kolsto, S. D. (2001) Scientific literacy for citizenship: tools for dealing with the science dimension of controversial socioscientifc issues, Science Education, 85, 291310 .

Lee, S. and Roth, W.-M. (2002) Learning science in the community, in: W.-M. Roth and J. Désautels (Eds) Science Education as/for sociopolitical action (New York, Peter Lang), 37-66.

Longbottom, J. E. and Butler, P. H. (1999) Why teach science? Setting rational goals for science education, Science Education, 83, 473-92.

Macdonald, S. (Ed.) (1998) The politics of display: museums, science, culture (London, Routledge). 
Millar, R. and Osborne, J. (Eds) (1998) Beyond 2000: science education for the future (London, King's College, School of Education).

Miller, J. (1983) Scientific literacy: a conceptual and empirical review, Daedalus, 112(2), 29-48.

Mortimer, E. F. and Scott, P. H. (2003) Meaning making in secondary science classrooms (Maidenhead, Open University Press).

Moussouri, T. (1997) Family agendas and family learning in hands-on museums, Unpublished $\mathrm{PhD}$ thesis (Leicester, University of Leicester).

Osborne, J. and Collins, S. (2001) Pupils' views of the role and value of the science curriculum: a focus-group study, International Journal of Science Education, 23, 44167.

Oulton, C., Dillon, J. and Grace, M. (2004) Reconceptualizing the teaching of controversial issues, International Journal of Science Education, 26, 411-23.

Parvin, J. and Stephenson, M. (2004) Learning science at industrial sites, in: M. Braund and M. J. Reiss (Eds) Learning science outside the classroom (London, RoutledgeFalmer), 129-49.

Popli, R. (1999) Scientific literacy for all citizens: different concepts and contents, Public Understanding of Science, 8, 123-137.

Price, S. and Rogers, Y. (in press) Let's get physical: the learning benefits of interacting in digitally augmented physical spaces Computers and Education.

Reiss, M. J. (2005) The importance of affect in science education, in: S. Alsop (Ed.) The affective dimensions of cognition: studies from education in the sciences (Dordrecht, Kluwer), 17-25.

Reiss, M. J. (in press) What should be the aim(s) of school science education? in: D. Corrigan, J. Dillon and R. Gunstone (Eds), The re-emergence of values in the science curriculum (Rotterdam, Sense).

Reiss, M. J. and Braund, M. (2004) Practicalities and safety issues, in: M. Braund and M. J. Reiss (Eds) Learning science outside the classroom (London, RoutledgeFalmer), 13-17.

Rennie, L. J. and McClafferty, T. P. (1996) Science centres and science learning, Studies in Science Education, 27, 53-98. 
Roth, W.-M. (1997) From everyday science to science education: how science and technology inspired curriculum design and classroom research, Science and Education, 6, 373-96.

Roth, W.-M. and Désautels, J. (Eds) (2002) Science education as/for sociopolitical Action (New York, Peter Lang).

Ryder, J. (2001) Identifying science understanding for functional scientific literacy, Studies in Science Education, 36, 1-44.

Shamos, M. H. (1995) The myth of scientific literacy (New Brunswick, Rutgers University Press).

Sjøberg. S. (1997) Scientific literacy and school science, in: S. Sjøberg and E. Kallerud (Eds) Science technology and citizenship: the public understanding of science and technology in science education and research policy (Oslo, Norwegian Institute for Studies in Research and Higher Education).

Sjøberg, S., Schreiner, C. and Stefánsson, K. (2004) The voice of the learners: international perspectives on S\&T based on the ROSE project. Paper presented at the $\mathrm{X} 1$ Symposium of the International Organisation for Science and Technology Education (IOSTE), Marie Curie-Sladowska University, Lublin, Poland, 25-30 July.

Swinbank, L. and Lunn, M. (2004) Learning physics and astronomy outside the classroom, in: M. Braund and M. J. Reiss (Eds) Learning science outside the classroom (London, RoutledgeFalmer), 169-83.

Thomas, J. (2000) Using current controversies in the classroom: opportunities and concerns, Melbourne Studies in Education, 41(2), 133-44.

Wellington, J. and Britto, J. (2004) Learning science through ICT at home, in: M. Braund and M. J. Reiss (Eds) Learning science outside the classroom (London, RoutledgeFalmer), 207-23.

Woolnough, B. (1998) Authentic science in schools, to develop personal knowledge, in: J. Wellington (Ed.) Practical work in school science. Which way now? (London, Routledge), 109-125.

Ziman, J. (2000) Real science: what it is, and what it means (Cambridge, Cambridge University Press). 